\title{
Changing Mindsets in the Info-Tech Enabled EFL Classroom
}

\author{
Noureddine Azmi \\ Faculty of Education \\ Mohammed V- Souissi University, Rabat-Morocco \\ azminoureddine@yahoo.fr
}

\section{Doi:10.5901/ajis.2013.v2n2p223}

\begin{abstract}
The present study investigates the impact of Info-Tech and the Internet in particular- on students' transformation of mindsetschanging assumptions and attitudes in the English language classroom. It gives an overview of perspective transformation in English language teaching through reviewing literature, critically analysing potential benefits of the use of Info-Tech -enabled transformative teaching in the language classroom; then moves to examine, through the use of an interpretive quantitative study, the impact of Info-Tech -enabled English language teaching on students' change and revision of mindsets. According to the findings, Info-Tech -enabled English language teaching environment enhances students' critical thinking skills, allows them to examine different meanings attributed to previous events and experiences and broadens their minds to include other cultural practices and values
\end{abstract}

Keywords: Info-Tech-enabled English language teaching; Transformative teaching and learning; Changing mindsets.

\section{Introduction}

The last reforms of the Moroccan educational system have introduced a new set of strategies and measures that challenge the old paradigms of teaching and call for the implementation of more innovative methodologies. Computer and Internet training programs have then been launched throughout the country to show the benefits of using Info-Tech in education and in foreign language teaching in particular, with less focus on the required methodologies and appropriate Info-Tech skills and pedagogies.

Virtual mobility (use of electronic media and online social networks to access sites, people, information, cultures and communities), when affordable and available, might pave the way for more English language learning inclusion and interaction with greater accessibility and participation in the Moroccan English language classroom . More and more foreign language professionals argue that Information and Communication Technology and virtual mobility in particular may ensure a more interactive and varied learning in the classroom. Web material is then used to supplement or even substitute text books, which raises questions and triggers debates about the appropriateness and implementation of new methodologies and teaching practices; and the eventual learning outcomes they may determine.

One of the growing concerns that may spark considerable controversy is whether the use of Info-Tech -enabled English language teaching brings about positive changes in the EFL classroom and triggers a transformation and revision of students' perspectives and mindsets. The present study investigates then the impact of Info-Tech use in the EFL classroom on students' mindset and perspective transformation; and sees if there is research evidence on how an English course content that utilizes Information technology triggers revision of belief and value system and helps change and reframe students' mindsets.

\section{Review of related literature}

\subsection{Using transformative teaching to change mindsets}

Transformational teaching/learning has triggered a large number of discussions and debates with growing concerns over its determinants and potential outcomes. Transformational learning is the process whereby learners critically examine and reflect on their own beliefs, assumptions and values through acquiring new knowledge and begin a process of personal and social change called 'reframing' in perspective transformation. J. Mezirow (1990). 
An individual, in the course of their life, may go through a dramatically different learning experience, be it institutional or informal, which may push them to reconsider pre-acquired views and meaning perspectives. If the individual manages to examine the view, open themselves to other alternatives and consequently change the way they see things, they have transformed some part of the way they perceive the world around them. The taken for granted frames of reference are transformed by making them more 'inclusive, discriminating, open, emotionally capable of change and reflective' ( Mezirow 2000)

Transformative or transformational learning occurs when the learner is forced to encounter an event or situation that is inconsistent with their existing perspective. Patricia Cranton (2002) has provided an overview of transformative teaching and explored ways in which educators may set up conditions to foster transformations. She has designed facets of transformative learning and introduced them as a guide to set up a learning environment to initiate change and promote transformation in the classroom.

\subsection{Info-Tech -enabled English language teaching can open minds}

The potential of Info-Tech - enabled English language teaching in the development and transformation of students' perspectives has been investigated by few researches and a large part of it has actually been devoted to the impact on the development of students' critical thinking skills. It is true that a change in perspectives takes place in the classroom, but its efficiency and usefulness is only a potential. Research has shown that English language learners experience a change in their mindsets and perspectives. Three themes of perspective transformation experiences usually emerge from the accounts of participants, language learning, cultural awareness and personal change. (Katleen P. King 2009). Participants recognise a change in their assumptions about the language, a development in intercultural awareness and a feeling of empowerment and self esteem through the learning of the language and its culture. While it is true that changes actually take place and that learners go through a transformation experience, it really is hard to agree on the appropriateness and usefulness of the changes themselves.

Though they are few, most conducted studies and researches reveal that EFL learners experience perspective transformation and the most common themes of the transformation experience mainly include the activation and acquisition of critical thinking skills.

The use of Info-tech may provide an ideal learning environment where critical thinking skills are enhanced and developed. Faizah Binti Mohamad (2004) from the International University of Malaysia investigated the effects of an Internet-assisted language learning (IALL) environment on the development of L2 students' critical thinking skills and found a significant improvement in students' critical thinking skills and a positive correlation between students' critical skills and their perception of the Internet. Students with a positive perception of the Internet were more likely to improve their critical thinking competencies.

With the use of Information Technology and the Internet in particular, English language professionals can help students interact, cooperate and actively contribute to the construction of their learning, which is likely to mark a shift of roles in the classroom. The Internet-enhanced environment offers students active learning roles and opportunities and requires them to go through advanced cognitive processes. This boosts their critical thinking skills and empowers them to evaluate and assess any piece of information they may encounter in the language classroom. Advocates and supporters of Information and Communication Technology in language teaching argue that unlike traditional instruction, computer assisted language learning fosters learner autonomy and help students develop individual learning strategies (Dennis E. Murray, 2000)

However, and since nobody can argue against the fact that the use of critical thinking skills is an advanced level of language learning and acquisition, a large number of students may be left behind in the Moroccan language classroom. Low achievers- students with language and linguistic deficiencies- may find it difficult to find a place in a learning setting where they are required to use advanced cognitive procedures and contribute to the development and construction of their own learning.

Info-Tech -enabled English language teaching environment does not only provide opportunity for the development of critical thinking skills, but also paves the way for perspective transformation and mindset rframing. Salem Ali Al-Salem (2005) argues that Saudi EFL college females have experienced perspective transformation as a result of their exposure to the information provided by the Internet as well as the mode of interaction facilitated via the Internet. The experience, he continues to explain, has increased their self confidence, broadened their minds about other cultures and given them 
more opportunities to make social contacts, which we think is a substantial step forward if we take into account the conservative aspect of the Saudi society.

Interaction within an Info-Tech -enabled EFL learning environment may contribute to a change in students' mindsets. Diane Susan (2002) conducted a research with intact groups of non-native English speakers enrolled in an Internet- aided ESL programme. The investigation showed that most of them experienced perspective transformation and concluded that class discussions largely contributed to the transformation experience. Both researchers found that interaction and class discussions, facilitated by the Internet, played a key role in the transformation experience and brought changes into the language classroom, which is again an extension of Mezirow theoretical theme of "critical reflection' and a recognition of the importance of critical thinking skills to the transformation experience.

In another study devoted to the investigation of how the use of Information Technology can enhance the process of transformative learning, Judith E. Parker (2005) examined qualitative comments from the end of course survey and reflection assignments and concluded that the use of both asynchronous discussion board and synchronous discussion (chat room) fostered the transformative learning characteristics of inclusion, openness and facilitated critical reflection. The world view was enhanced during the online format of classes through making it possible for students from other places of the world with different views to participate in the course. Given these claims, there seems to be then little dispute about the potential impact of Information Technology use on learners' perspective transformation and mindset change in the EFL classroom.

\section{Methodology}

\subsection{Qualitative/ quantitative content analysis}

Qualitative/quantitative content analysis is not only counting words or examining meanings, themes, tendencies or patterns, it also allows researchers to investigate issues using a scientific procedure. The main reason for conducting content analysis is to be able to investigate and establish, if possible, links between the implementation of Info-Tech in the English language classroom and the possibility of changing and reframing students' mindsets. When students are exposed to Info-Tech -enabled learning material that includes controversial issues that are inconsistent with their existing perspectives, they are more likely to reflect on their learning experience and transform their perspectives and reframe their minds.

The process of content analysis includes the following steps:

- Selecting, determining and coding units of content

- Counting and weighing

- Drawing conclusions

Students were asked to submit paragraphs about a set of controversial social issues. They were told to react to a set of writing prompts and use specific reasons and examples to support their position. Many students from the experimental group volunteered to give Info-Tech - enabled presentations on the same writing prompts- Internet regulation, euthanasia, forced abortion and volunteering and solidarity. They were encouraged to use web material and introduce controversial views along side with their own comments and reactions; while students from the control group didn't attend any Info-Tech- enabled presentations and were required to react to the same writing prompts. Since the scope of this study does not allow us to include reactions to all writing prompts, we have narrowed the study to include content analysis of paragraphs related to one writing prompt.

\subsection{Writing prompt}

The Internet includes many websites with content that is inappropriate for children. Should websites like these be censored? Why or why not? State your position and support it with specific reasons and examples.

\subsection{Research question}

To what extent does Info-Tech -enhanced English language teaching make students transform their perspectives and reframe their mindsets? 


\subsection{Research hypothesis}

Info-Tech -enhanced English language teaching contributes to the development of students' critical thinking skills, but does not trigger revision and change of mindsets.

\section{Presentation and discussion of findings}

\subsection{Selecting, determining and coding units of content}

\subsubsection{Experimental group}

\begin{tabular}{|c|c|c|}
\hline \multicolumn{2}{|r|}{ Target content pattern: argument used to back up positions } & Code \\
\hline 1 & $\begin{array}{l}\text { The Internet is censored in order to enable adults to protect children from harmful material } \\
\text { and give them a good education. }\end{array}$ & A \\
\hline 2 & $\begin{array}{l}\text { Parental censorship should be maintained until children are old enough to distinguish right } \\
\text { from wrong. }\end{array}$ & A \\
\hline 3 & $\begin{array}{l}\text { Inappropriate material and pornographic content in particular should be censored to protect } \\
\text { children. }\end{array}$ & A \\
\hline 4 & Censorship protects children but they will always find a way to access pornographic material. & $\mathrm{F}$ \\
\hline 5 & $\begin{array}{l}\text { The Internet should be regulated to monitor children's use and protect them from the dark } \\
\text { side of the web. }\end{array}$ & A \\
\hline 6 & Using the filter is likely to protect children from the negative influences of the web & A \\
\hline 7 & Explict material (pornography) exercises a negative influence on kids' social behaviour & A \\
\hline 8 & When the filter is used; children will know at least that what they are doing is wrong. & A \\
\hline 9 & $\begin{array}{l}\text { Censorship of Internet communications could never be achieved. Children should be } \\
\text { coached. }\end{array}$ & $\mathrm{F}$ \\
\hline 10 & It is not possible to censor the Internet. Children should be trained to choose and select & $\mathrm{F}$ \\
\hline
\end{tabular}

\subsubsection{Control group}

\begin{tabular}{|l|l|l|}
\hline \multicolumn{2}{|c|}{ Target content pattern: argument used to back up positions } & Code \\
\hline 1 & $\begin{array}{l}\text { The Internet must be censored to protect children from the harmful effect of explicit web } \\
\text { content }\end{array}$ & $\mathrm{A}$ \\
\hline 2 & I am against censorship. Children will learn through experience & $\mathrm{F}$ \\
\hline 3 & Censorship will allow children to know that accessing inappropriate material is wrong & $\mathrm{A}$ \\
\hline 4 & $\begin{array}{l}\text { Even if children manage to access inappropriate material elsewhere they know that what they } \\
\text { do is wrong. }\end{array}$ & $\mathrm{A}$ \\
\hline 5 & Children should have an idea about inappropriate material. & $\mathrm{F}$ \\
\hline 6 & Using the filter will protect children from harmful content. & $\mathrm{A}$ \\
\hline 7 & Accessing inappropriate material may have dangerous consequences & $\mathrm{A}$ \\
\hline 8 & Inappropriate material should be censored to protect and educate children. & $\mathrm{A}$ \\
\hline 9 & $\begin{array}{l}\text { Protecting children from the dangerous consequences of inappropriate material is part of } \\
\text { their education }\end{array}$ & $\mathrm{A}$ \\
\hline 10 & Inappropriate material should be censored because It may damage children's mind capacities & $\mathrm{A}$ \\
\hline
\end{tabular}

Arguments of both groups were summed up and reduced to include only pertinent content then were coded in either $\mathrm{F}$ or A to simplify the process of their counting and weighing later. Irrelevant content was disregarded from presentation and analysis. 


\subsection{Counting and weighing}

perspective * group Cross tabulation

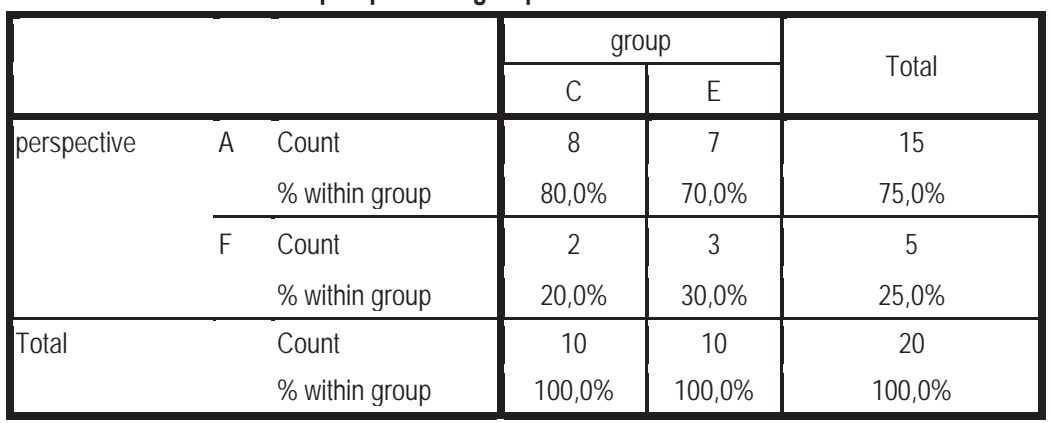

The sample includes 20 arguments used by students to support their position towards Internet regulation. A big majority of participant students (80\%) from the control group maintained the conventional position towards Internet regulationcensorship; while about (70\%) of participant students from the experimental group did so. About a third (30\%) of participant students from the experimental group have managed to examine the view and open themselves to other alternatives while only a fifth (20\%) of participant students from the control group have done so. Only the implementation and interpretation of the Chi-Square Tests would determine differences among groups and help answer the research question.

\section{Chi-Square Tests}

\begin{tabular}{|l|c|c|c|c|c|}
\hline & Value & df & $\begin{array}{c}\text { Asymp. Sig. (2- } \\
\text { sided) }\end{array}$ & $\begin{array}{c}\text { Exact Sig. (2- } \\
\text { sided) }\end{array}$ & Exact Sig. (1-sided) \\
\hline Pearson Chi-Square &, $267 a$ & 1 &, 606 & & \\
Continuity Correction &, 000 & 1 & 1,000 & & \\
Likelihood Ratio &, 268 & 1 &, 605 & \multirow{2}{*}{, 500} \\
Fisher's Exact Test & 20 & & & 1,000 & \\
N of Valid Cases & & & & \\
\hline
\end{tabular}

a. 2 cells $(50,0 \%)$ have expected count less than 5 . The minimum expected count is 2,50 .

\section{Test result}

Since more than (50\%) of the contingency cells have expected values $<5$, it would be more appropriate to consider the Fisher's Exact Test outcome. The results from the Fisher's Exact Test outcome indicate that there is no statistically significant relationship between students' change and revision of mindset and Info-Tech -enabled English language teaching. $(p=1.000>0.05)$.

\subsection{Drawing conclusions}

It appears from the observed patterns, at least tentatively, that there are associations between students' change and revision of mindsets and Info-Tech -enabled English language teaching. But, the results from the Fisher's Exact Test outcome indicate that there is no statistically significant relationship between the two variables, which backs up the null hypothesis that Info-Tech -enhanced English language teaching does not trigger students' revision of value system and change of mindsets. However, the examination of writing assignments shows that the use of Info-Tech -enabled English language teaching fosters the transformative learning characteristics of engagement, openness and facilitates critical reflection. 
The Info-Tech -enhanced environment offers students active learning roles and opportunities and requires them to go through advanced cognitive processes. This has boosted their critical thinking skills and empowered them to evaluate and assess pieces of information they have encountered in the language classroom. Unlike the control group, students from the experimental group have been able to examine the view and provide a large set of well-fleshed up arguments to back up their positions.

- The internet is censored in order to enable adults to protect children from harmful material.

- Censorship protects children but they will always find a way to access pornographic material.

- It is not possible to censor the Internet. Children should be trained to choose and select.

- Children will know at least that what they are doing is wrong.

- Explicit material exercises a negative influence on kids' social behaviour.

Participant students from the control group were able to produce arguments, too. But most of them have limited themselves to describing inappropriate material as a danger.

\section{Conclusion}

While it is true that the exposure to Info-Tech -enabled class content did not bring about any considerable changes in students' perspectives and mindsets, the experience has increased students self confidence, broadened their minds about other perspectives and given them more opportunities to voice their opinions, which we think is a substantial step forward if we take into account the conservative aspect of the Moroccan society.

Analysis of students' reactions to other writing prompts that are not included in this study has revealed that InfoTech -enabled EFL instruction has triggered a change in students' mindsets. Students have managed to open themselves to other alternatives and were able to change their perspectives and adopt views. However, the objective for an EFL teacher is not to make their learners reconsider and reframe pre-established views and perspectives. What counts more is the provision of an interactive teaching platform that increases participatory learning and allows learners to develop critical thinking skills and attitudes.

\section{References}

Beth F. Yoshida and Kathy D. Geller, Innovations in transformative learning space, culture and the arts. Peter Lang Publishing Inc (2009)

Cranton, P., Understanding and Promoting Transformative Learning. San Francisco: Jossey Bass (1994)

Kathleen, P. King, Handbook of the evolving research of transformative learning. Information Age publishing INC, (2009)

Lori Langer De Ramirez, Empower English Language Learners with Tools from the Web. Corwin, a Sage Company (2010)

Martin Bloomer, Young Lives, Learning and Transformation: Some Theoretical Considerations. Oxford Review of Education, Vol. 27, No. $3(2001)$

Marguerite Jamieson, Rebecca Kajs, Anne Agee, Computer-Assisted Techniques to Enhance Transformative Learning in First-Year Literature Courses. Computers and the Humanities, Vol. 30, No. 2 (1996)

Mezirow, J. Transformative Dimensions of Adult Learning. San Francisco: Jossey-Bass,(1991)

Mezirow, J. "Transformative Learning: Theory to Practice." In P. Cranton (ed.), Transformative Learning in Action: Insights from Practice. New Directions in Adult and Continuing Education, no. 74. San Francisco: Jossey-Bass, (1997)

Mezirow, J., and others. Learning as Transformation: Critical Perspectives on a Theory in Progress. San Francisco: Jossey-Bass, (2000)

Salem Ali Al-Salem, The impact of the Internet on Saudi Arabian EFL females' self-image and social attitudes. Indiana University of Pennsylvania (2005)

Susan L. Stansberry and Angel D. Kymes, Transformative Learning through "Teaching With Technology" Electronic Portfolios. Journal of Adolescent \& Adult Literacy, Vol. 50, No. 6, Electronic Portfolios (2007)

Will Richardson, Blogs, podcasts and other powerful tools for the classroom. Corwin Press, 2nd Ed, (2008) 